\title{
Organism life cycles, predation, and the structure of marine pelagic ecosystems
}

\author{
Peter G. Verity ${ }^{1, *}$, Victor Smetacek ${ }^{2}$ \\ ${ }^{1}$ Skidaway Institute of Oceanography, 10 Ocean Science Circle, Savannah, Georgia 31411, USA \\ ${ }^{2}$ Alfred Wegener Institute for Polar and Marine Research, Am Handelshaien 12, D-27570 Bremerhaven, Germany
}

\begin{abstract}
This paper explores the notion that the theoretical basis for contemporary research concerning the structure and function of marine pelagic ecosystems is self-limiting. While some findings such as the microbial food web have extended our knowledge of the biological components of the upper water column and their relationships to fluxes of materials and energy, they have not advanced our understanding of why specific pelagic forms occur in time and space, and why only some attain dominant status and contribute the bulk of biogenic fluxes emanating from the mixed layer. It is argued here that a major impediment to improved conceptual models is the historic focus on resource-driven or 'bottom-up' factors as being the dominant variables structuring planktonic ecosystems. Evidence is presented that predation or 'top-down' trophic effects may be equally important in specifying the occurrence of particular taxa, the biomass within adjacent trophic levels, and the morphology of dominant herbivores and carnivores. It is suggested that key species, because of unique combinations of life history strategies, metabolic demands, and physiological performance, may exert a dominant role in the extent to which predatory interactions cascade through pelagic food webs. There is considerable evidence of evolution of predation avoidance strategies among phytoplankton and zooplankton. It is proposed that future research might profitably be directed toward the question of how the pelagic environment selects for life histories and morphologies of organisms under conditions when resource availability and predation are both significant structural buttresses. Methodological approaches should include detailed studies of dominant key taxa from different environments, with the goal of identifying the critical aspects of life history, behavior, or morphology which account for their success.
\end{abstract}

KEY WORDS: Morphology · Life history · Plankton - Pelagic - Top-down - Trophic cascade · Predation . Ecosystem structure $\cdot$ Bottom-up

\section{CONCEPTUAL OVERVIEW}

Quantitative understanding of marine processes has increased rapidly in the past decades, driven by the development of new methods and tools enabling measurement, mapping and modelling of the fluxes and cycling of biogenic elements, at scales extending from molecular diffusion to global ocean circulation. However, these substantial advances in quantification and delineation of biogeochemical processes and provinces have not been accompanied by commensurate progress in understanding of the mechanisms

•E-mail:peter@skio.peachnet.edu that structure pelagic ecosystems. Thus, the distribution patterns of dominant pelagic species are fairly well established, yet we do not know why they occur when and where they do. What is lacking is knowledge of the nature of properties that gear given species to specific environments, and which are responsible for their occurrence or persistence in given water masses.

For example, we do not clearly understand why only a few diatom genera dominate oceanic new production, or why calanoid copepods contribute the bulk of marine zooplankton biomass. These are important questions because the respective diatoms and copepods each impact the fate of organic matter produced or processed by them in unique ways: the silica frus- 
tules of diatoms and the compact fecal pellets of copepods both enhance vertical flux of organic matter. In contrast, the gelatinous colonies of Phaeocystis, which dominate new production in some environments, often contribute less to vertical flux than the equivalent biomass of diatoms (Wassmann 1994). Further, Daphnia, the dominant zooplankter in many lakes, produces loose fecal matter that disintegrates following release (Lampert 1987) and hence does not contribute to vertical flux. Thus, neither of these properties - silica frustules or fecal pellets - can presently be related to the dominant role diatoms and copepods play in the marine pelagial.

The above examples illustrate the extent to which biological properties of dominant organisms determine patterns of biogeochemical cycling in today's ocean, but they also demonstrate the substantial gaps that still exist in our understanding of marine ecological processes and seriously hamper further progress. The traditional approach to the study of marine pelagic ecology is biased toward factors regulating growth of organisms, i.e. resource acquisition (bottomup force) is accorded more importance than predation (top-down force) in regulating the structure and functioning of marine pelagic systems. We argue that this approach is now self-limiting, as it has not provided an adequate framework to advance our understanding of how natural selection works in the marine pelagial.

We advocate here that predation and resource availability act through morphologies and life history strategies of organisms to structure pelagic ecosystems, and hence to drive biogeochemical cycles. The potential significance of the biological pump (organism-mediated incorporation of inorganic carbon into organic carbon, and its sequestration into the interior ocean via downward flux of biogenic particles), and our uncertainty in resolving that role (Longhurst \& Harrison 1989), speaks volumes for the need of an improved mechanistic understanding of the linkages between cause and effect in plankton dynamics. For example, changes in food web structure have been associated with altered patterns of vertical flux in Lake Michigan, North America (Kitchell \& Carpenter 1987), and in the North Atlantic Ocean (Sieracki et al. 1993). In other words, changes in structural components of the pump lead to changes in how the pump works. But what are the linkages, and how do the biological components direct one another? The ideas which follow are by no means designed to promote one architectural principle over another (e.g. resource limitation vs predation), but to emphasize that it may be more valuable to understand why carbon flows where it does, rather than merely how much.

\section{THE ROLE OF ORGANISM LIFE CYCLES AND MORPHOLOGIES}

The bulk of large-scale biogenic cycling and production of fish food is dependent on relatively few taxa and morphotypes. In the following sections, we discuss some examples of key species and their morphologies to illustrate how specific knowledge of individual biologies will greatly improve our understanding of the forces shaping ecosystem structure and driving biogeochemical fluxes. This information holds considerable promise for development of a predictive framework.

Fragilariopsis (Nitzschia) kerguelensis. This is a medium-sized (15 to $30 \mu \mathrm{m}$ long) pennate diatom that lives in ribbon-shaped chains of 20 to 100 cells and forms almost monospecific blooms in the Antarctic Polar Frontal Zone (Bathmann et al. 1994). Its global significance is bestowed by its inordinately robust siliceous cell walls, which contribute the bulk of the silica deposits in the underlying sediments (Burckle \& Cirilli 1987). Indeed, deposition of its frustules has continued unabated through glacial and interglacial cycles. This siliceous girdle around the continent is reputed to accumulate fully $75 \%$ of the biogenic silica being deposited in today's ocean (Ledford-Hoffman et al. 1986), although only $20 \%$ of global biogenic silica production occurs in these waters (Treguer et al. 1995). It is tempting to speculate that the thick cell wall of $F$. kerguelensis is somehow selected for as a grazer deterrent in these waters, inducing blooms and mass sedimentation. It follows that these factors, be they sinking and seeding strategy (sensu Smetacek 1985), or grazer protection, or both, indirectly shape the ocean silica budget. But what are these factors?

Emiliania huxleyi. This is a small $(<10 \mu \mathrm{m})$ coccolithophorid that forms blooms in many different regions of the world oceans in both high and low latitudes (Brown \& Yoder 1994) but also from oceanic to coastal regimes (Berge 1962). Its sedimentary record indicates that this amazing ability to grow to bloom proportions under such a wide variety of conditions has developed only since the Holocene. Prior to the last Ice Age. another small species (Gephyrocapsa), now of minor importance, dominated coccolithophorid blooms. Circumstantial evidence from mesocosm studies implicates viral attack rather than nutrient exhaustion in the demise of 2 Emiliania blooms studied in successive years (Bratbak et al. 1993). Indeed, Emiliani (1993) himself suggested that viral infections were a significant factor in driving species extinctions in marine plankton. Although biogeochemical fluxes (dimethyl sulfide or DMS, and carbonate) mediated by this species are only important on a regional scale (Brown \& Yoder 1994), its extraordinary ecological flexibility cries out for elucida- 
tion. Molecular genetic studies indicate that open ocean and coastal forms belong to the same species (Barker et al. 1994); however, when clonal cultures from the same mesocosm experiment were compared with one another, a surprising degree of genetic variability within the bloom population came to light. Emiliania is indeed a tantalizing species

Phaeocystis. This is a polymorphic phytoplankton taxon whose life cycle includes, but may not be limited to, solitary flagellated cells of 3 to $8 \mu \mathrm{m}$ and gelatinous colonies of non-flagellated cells up to $2 \mathrm{~cm}$ in diameter (Kornmann 1955, Verity et al. 1988, Rousseau et al. 1994). While some uncertainty remains about taxonomic identity, details of its life cycle, and transitions therein (Baumann et al. 1994, Cariou et al. 1994, Medlin et al. 1994), Phaeocystis is well known for prodigious blooms of the colonial phase. These occur primarily in boreal and polar waters of both hemispheres, but occasionally in temperate and tropical waters (Kashkin 1963, Baumann et al. 1994). These blooms are important regionally and seasonally to primary production, and their significance to global $\mathrm{CO}_{2}$ sinks has also been promoted (Smith et al. 1991). There is evidence that changes in the size structure of Phaeocystis blooms can alter the zooplankton community (Hansen et al. 1994), and that omnivorous zooplankton in the presence of Phaeocystis prey instead on protozoans, thereby releasing Phaeocystis from herbivory (Hansen et al. 1993). In the absence of substantial grazing pressure, sedimentation of colonies occurs in some environments (Wassmann 1994), although emigration of cells out of the colonies might minimize vertical export of cellular carbon (Verity et al. 1988). Phaeocystis is also a copious producer of DMS and its precursor in seawater, DMSP (Stefels \& van Boekel 1993), so that Phaeocystis may be important to global sulfur balances, acidification of atmospheric aerosols and rain, and climate change (see Liss et al. 1994 for review). Thus, factors influencing its productivity and fate may significantly and interactively affect biogeochemical cycling. However, the fate of Phaeocystis colony blooms seems intrinsically associated with its life cycle and the associated match or mismatch with herbivores.

Euphausia superba. Antarctic krill is the key species of the Southern Ocean, as it maintains an enormous biomass (still in excess of Homo sapiens) in an area only twice the size of the USA. Its average density, using conservative stock estimates, is at least 10 to 30 ind. $\mathrm{m}^{-2}$, equivalent to 1 to $3 \mathrm{~g} \mathrm{C} \mathrm{m}^{-2}$ ! None of the other species of pelagic euphausiids are as prominent in their respective habitats as krill in the Southern Ocean; therefore, the unique status of krill has to be explained by unique features of its biology and/or its habitat.
Apart from its larger size, krill is very similar to other euphausiids, hence any unique ability is not reflected in its morphology. Productivity of the krill habitat - the region bounded by the winter extent of sea ice around Antarctica - is rather low and the composition and biomass of plankton, contrary to earlier belief, is similar to that of other high latitude oceans (Smetacek et al. 1990). Krill utilizes a wide range of food sources: phytoplankton, ice algae (Marschall 1988) and copepods (Huntley et al. 1994) and can easily survive long periods of starvation (lkeda \& Dixon 1982). Clearly, versatility is necessary if such a large portion of the annual primary production is to be sequestered in a single population, and Smetacek et al. (1990) argued that it is the way in which Euphausia superba has geared its life cycle to the seasonality of sea ice that enables it to maintain such large stocks. However, a notable feature of krill is its long life span, and consensus is now emerging that individuals live for at least 5 or 6 yr (Knox 1994), which is very unusual among pelagic crustacea and implies a slower turnover rate of the population than was previously believed. It follows that the exceptional stock size of krill when compared to euphausiid populations of other oceans cannot be explained by a faster growth rate but is more likely due to a lower mortality rate, as discussed below.

The unique feature of the krill habitat is the presence of the seasonal sea ice cover which is utilized by krill as a food source but which also offers protection, particularly during winter, from the air breathing, visual predators that are the chief predators of krill. Another unique feature of the krill habitat is the relative absence of clupeid type fish swarms. Although a clupeid morphotype has evolved in the Antarctic (Pleurogramma antarcticus), its predation pressure on local euphausiids is negligible compared to that of e.g. capelin, herring, or sardines in their respective habitats. We speculate that this is due to the stress that hypoosmotic teleosts would experience in continuous, close contact with sea ice. Whatever the reason, the fact remains that their relative absence reduces predation pressure not only on krill but also on their alternative food, copepods, which are hence available to krill. Indeed, the actively foraging krill swarms encountered in open water during summer are themselves reminiscent of clupeid fish. It follows that the presence of sea ice, by changing predation patterns, leads to a biomass bulge in the euphausiid group, which in turn has considerable ramifications for the structure and population dynamics of the predators. The implications of the krill example for our conceptual view of factors constraining marine zooplankton populations are discussed next. 
The organisms described above represent but a few examples of species whose morphologies or life history strategies are sufficiently successful that they dominate their respective environments in time and space. They may hold space because they sequester resources (bottom-up structuring) better than their rivals, or because they avoid or inhibit predators (top-down structuring). The former strategy has generally attracted the most attention in marine plankton research. We consider in the following sections some conceptual arguments on why equal attention should be focussed upon the significance of predation, and the potential selective pressure of avoiding being eaten, in conceptual models of food web structure and biogeochemical fluxes in the marine pelagial.

\section{PREDATION CONSTRAINTS ON ZOOPLANKTON MORPHOLOGY}

Oceanic zooplankton are the most widespread form of animal life on earth with the longest history of evolutionary continuity. Yet the number of taxa is orders of magnitude smaller than that of the marine benthos. Furthermore, the bulk of the biomass is present within only a few morphotypes represented by dominant species of copepods, euphausiids, pteropods, and chaetognaths. Among holoplankton, the same basic body shape is maintained through 10 to $100 \times$ variation in body volume in many cases. The special case of gelatinous zooplankton is further discussed below. The perceived similarity within the groups just mentioned is all the more striking when compared with morphological variation within the major benthic groups. Here we discuss the respective roles of food acquisition and predator avoidance as constraints on morphology using the most ubiquitous form, the epipelagic copepods, as an example of a highly successful body shape.

The similar morphology of calanoid copepods which is retained through about 2 orders of magnitude range in length contrasts strikingly with the degree of genetic variation (Bucklin et al. 1995), suggesting strong environmental constraints on morphology. The constraints do not appear to be dictated by food acquisition strategies because copepods as a group are known to feed on a wide variety of foods ranging from small suspended particles to zooplankton of equal size. Indeed, gut contents and the actual process of feeding need to be examined if one is to find out what constitutes the major food sources of the various species (Paffenhöfer 1988, Turner 1991). It follows that food acquisition (bottom-up control) is not a major determinant of general body shape of epipelagic copepods.
Life history patterns also vary widely, ranging from an apparent absence of seasonality, even in polar waters, to presence of diapausing eggs in coastal species and diapausing sub-adults in many oceanic copepods (Smith \& Schnack-Schiel 1990). Again, a particular life history does not select the morphology of the various life cycle stages that all copepods undergo, although geographical distribution of the various species is probably constrained by this factor. Differences in reproductive behavior are manifested in relatively minor details such as morphology of appendages involved in transfer of sperm, although females of some species carry conspicuous egg sacs while others release them as they are produced. We are left with predation as the major constraint on copepod morphology and several arguments can be broached in support of this.

Firstly, all copepods throughout their respective ranges share the same types of predators: active hunters such as chaetognaths and fish, and passive trappers such as jellies and foraminifera. Most copepod predators are too large to be deterred by defenses such as spines or thick carapaces formed in limnetic cladocerans and none of these have been developed by copepods. Camouflage from visual hunters is effected by small size and transparency but also by avoiding the epipelagial during the day, using diel vertical migration (DVM), and both of these properties are well developed in copepods. Hays et al. (1994), in a comprehensive study of DVM behavior in copepod species across the North Atlantic, found that large and pigmented species migrated more. They concluded that the risk of predation from visual predators [is] the most important factor influencing taxonomic differences in DVM'.

Upon detection, escape from attacking predators is by flight and, to our knowledge, all copepods can 'jump' considerable distances when threatened. Hardy (1956) stated 'if it (Calanus) makes a sudden spurt the first antennae fold back to offer the least resistance', propulsion being effected by the 'oar-like thoracic limbs'. The much shorter antennae of those copepods with well-developed eyes (e.g Corycaeus) suggest a sensory (mechano-tactile) function of these appendages. Experimental studies indicate that the first antennae are environmental sensors (Gill \& Crisp 1985, Bundy \& Paffenhöfer 1993), which could function to perceive food (Paffenhöfer \& Lewis 1990) or predators. Support for the latter comes from those species in which adult males cease feeding and reduce their mouth parts whereby the first antennae and the basic morphology are retained, although locating females by e.g. pheromones will also be an important function. Indeed, in some male copepods, one of the antennae is hinged and used to embrace the female during mating 
(Hardy 1956). Apart from this minor modification, male and female antennae are so similar that one would expect the same function in both sexes. Escaping predation is, of course, equally as important in males as in females. Short-range predator recognition would be worthless were it not followed by an effective escape response, which is a common feature of copepods. Indeed, about two-thirds of the body is occupied by the segments carrying the thoracic limbs responsible for flight. Vertical migration and horizontal swimming is also effected by these limbs, although slower speeds require correspondingly less investment in muscle. In the absence of evidence to the contrary, we suggest that the characteristic shape of the cephalothorax of copepods is selected more by flight ability from predators (top-down) than by foraging efficiency (bottom up).

That genetic constraints on morphotype are not involved is amply demonstrated by the diverse grotesque morphologies of parasitic copepods that attach themselves to much larger hosts. These aberrant forms belong to the Poecilostomatoida and cyclopoid groups which in general exhibit much greater morphological plasticity than the more common calanoids. Steinberg et al. (1994) found that copepods were the most numerous animals living on discarded larvacean houses at midwater depths (100 to $500 \mathrm{~m}$ ) and that many of these species 'possess benthic-like morphology and feeding strategy'. This example also indicates that morphology can well be modified to improve food acquisition. However, these species are only common below the depth where visual predation is efficient. The dominant cyclopoid genus in the epipelagial, Oithona, has a morphology remarkably similar to that of the common calanoids. Thus, a substantial case can be argued for predation as a major factor constraining copepod morphology. In the past, feeding behavior of marine copepods has received much more attention than mechanisms of predator avoidance (see Kerfoot \& Sih 1987 for freshwater zooplankton). This imbalance now needs to be rectified. We dwell next on some implications for pelagic food web structure.

We have argued that the characteristic copepod morphology is an effective way of avoiding predation in their respective size class. Further up the size spectrum, the euphausiid morphology, also shared by mysids and decapod shrimps, appears to be a better way of avoiding predators and maintaining large stock size. In this morphological group, the large muscular abdomen is used for the typical tail-flip flight mode, which differs strikingly from the 'normal' swimming pattern. The large investment in body tissue solely for flight is very evident here. The streamlined form of chaetognaths and juvenile fish will be equally effective in capturing motile prey and escaping predators; how- ever, each uses a different strategy. Both rely on transparency to disguise themselves from predator and prey. The typical motionless hunting behavior of chaetognaths, interrupted by short distance darts for prey capture, further contributes to their invisibility. However, while fish larvae are also comparatively transparent, their well-developed pigmented eyes are not; this undoubtably increases both their detection of prey and their perception by predators. In contrast, chaetognaths have almost completely eliminated pigmented organs and instead rely upon sensory hairs to detect prey and predator (R. L. Hopcroft pers. comm.).

So far we have only considered the non-gelatinous zooplankton that provide the bulk of the food for commercially important fish stocks. The biomass of gelatinous zooplankton (hereafter called jellies), e.g. coelenterates, ctenophores, salps and doliolids, does not flow up the economically important food chain and, because they eat the same food as the other zooplankters, they have long been considered a trophic dead-end, perhaps unjustly, since over 100 fish species are reported to occasionally or regularly ingest jellies (G. R. Harbison pers. comm.). Perhaps freed from the need to escape from attacking predators, jellies exhibit a much wider range of shapes than their more muscular counterparts. For example, 3 ctenophore genera (Pleurobrachia, Beroe, and Mnemiopsis) have strikingly different morphologies, each associated with a specific food acquisition strategy. In coelenterates, too, the range in body shape is wider than e.g. among freeliving copepods, and feeding behavior is more easily apparent. Furthermore, the barrel-shaped body plan of salps and doliolids can be readily explained solely on the basis of food acquisition.

The common feature of jellies is their high volume: plasma ratio, which is widely believed to deter predators because of its low nutritional value. However, the constraints on eating jellies must be more subtle, as there are enough examples of non-gelatinous predators of jellies (e.g. pelagic turtles, moon-fish, stromateoid fishes) to show that vertebrates can indeed make a living off jellies. But turtles and moon-fish are morphologically very different from the standard pelagic fish shape (exemplified by clupeids), and the stromateoid fish have a crop in their digestive system (Bühler 1930) presumably to facilitate feeding on jellies (G. R. Harbison pers. comm.). The question is, why are jellies not a principal dietary component of commercially important fish? The answer may reflect the sleek, streamlined form of the dominant epipelagic fish which, as in the case of the zooplankters, is maintained over several orders of magnitude (from anchovies to tuna). The bodies of these fish consist largely of flight muscle: 80 to $95 \%$ of the swimming musculature is white muscle which enables the high velocities neces- 
sary to avoid predators or to capture prey, with a correspondingly lesser investment in red muscle dedicated to 'normal' swimming (Bone 1978, Driedzic \& Hochachka 1978). As in the case of copepods, fish body form deviates, often grossly, from the streamlined form wherever the environment offers protection from visual predators. This is exemplified by the grotesque shapes of deep sea fish and by surface-living Sargassum fish that are models of effective camouflage. While streamlining may facilitate rapid motions to capture prey (Kils 1990), the above considerations imply that escape from predators may be equally or more important than resource acquisition in constraining morphotype of epipelagic fishes. (Among lizards, for example, speed is used for escape from predation rather than food capture; Hertz et al. 1988.) This streamlining may also be the selective factor primarily responsible for the development of gape limitation in pelagic systems (Hairston \& Hairston 1993). In contrast, a diet compased solely of jellies inevitably requires large gut volume, and a 'belly full of jelly', by producing drag, will critically reduce escape speed. It follows that exclusive jelly feeders will not be able to maintain the body form and muscle necessary for survival in the epipelagial, and we suggest that this may be the underlying reason for the dichotomy between the muscular and the gelatinous food chains. As always in nature, exceptions do occur, such as in streamlined mackerel actively preying on small medusae in the laboratory (Runge et al. 1987) and on salps in nature (Konchina 1991); however, such events are unlikely to reflect the principal diets of these and similar-bodied fish, given the highly episodic nature of abundant distributions of gelatinous planktonic organisms. Conversely, perhaps the potential ability of a school of predatory fish to nearly exterminate a patch of jellies favored another life history strategy: the very high rates of population growth characteristic of smaller gelatinous forms, e.g. salps, doliolids.

\section{PREDATION AVOIDANCE AND THE ARMS RACE}

It is a delicate balance to find sufficient food while avoiding being eaten and there are several hypotheses describing the interdependent nature of organisms in evolution. It is generally recognized that terrestrial plants coevolve with their insect herbivores (Ehrlich \& Raven 1.964, Strong et al. 1984), with attendant costs, e.g. plant growth rates are inversely proportional to their chemical defenses (Coley et al. 1985). Another theory, recently termed escalation (Vermeij 1994), proposes that enemies are the primary agents of natural selection among organisms, and that predationinduced adaptations direct long-term behavioral and morphological traits. This theory, described elsewhere as an 'arms race' (Dawkins 1987), proposes that as predators evolve more effective weapons systems, prey match these advances with equally successful antidotes. These arms races do not escalate out of control, or evolve into perfect capturing and escaping machines, because biological weaponry (e.g. speed to capture prey or to escape predators) must be bought at some other escalating cost (e.g. decreasing reproductive success).

Signor \& Vermeij (1994) hypothesized that herbivorous and carnivorous plankton originally evolved as refuges from predation by marine benthic organisms. The present paper argues that the concept of the arms race is currently applicable to the marine pelagial, where if predation is so important, selection for predator avoidance mechanisms should be evident. Among plankton, predator avoidance strategies appear well developed, though perhaps not broadly distributed, and fall into 4 general categories: chemical, morphological, behavioral, and life history defenses. A few of these are described below; the reader is also directed towards detailed reviews elsewhere (Havel 1987, Sih 1987). Predation avoidance has also recently been evaluated as a selection pressure acting on bacteria (Jürgens \& Güde 1994).

Chemical defenses. Several classes of phytoplankton are known to include taxa which are inhibitory or toxic to herbivores. Examples include the presumed raphidophyte Olisthodiscus luteus/Heterosigma akashiwo (Verity \& Stoecker 1982, Van Alstyne 1986); several dinoflagellates (Huntley et al. 1986, Taniguchi \& Takeda 1988); and the freshwater cyanophytes Microcystis and Aphanizomenon (Fulton \& Paerl 1987, Jungmann et al. 1991). The active agents are generally unknown but presumed to be secondary metabolites sequestered within the cells (Faulkner 1984, Carmichael 1986). Some diatoms apparently contain or excrete chemical compounds which interfere or inhibit grazing by copepods (Malej \& Harris 1993) and reduce egg production and hatching success (Poulet et al. 1994). While it cannot be certain that such compounds evolved in response to predation, i.e. allelochemical interactions within a trophic level may also be important (Lewis 1986), they are widely recognized for their role in deterring herbivory in terrestrial plants (Schultz 1988) and macroalgae (Hay \& Fenical 1988), Lowered nutritional quality, independent of toxins or compounds which reduce digestibility, can also affect susceptibility to predation (Butler et al. 1989). Induction of chemical defenses in plankton are inadequately understood.

Morphological defenses. These include both fixed and inducible morphologies (Havel 1987). Among defensive changes in prey architecture that have been ex- 
perimentally verified are: formation of colonies by previously single-celled Scenedesmus when exposed to herbivorous zooplankton (Hessen \& Van Donk 1993 Lampert et al. 1994); growth of neck spines by Daphnia when exposed to kairomones of invertebrate predators, a process which is stage- and concentration-dependent (Tollrian 1993); development of extended wings and ridges by grazing ciliates when exposed to larger predatory ciliates (Kuhlmann \& Heckmann 1985); and growth of spines by rotifers to deter predation by larger zooplankton (Stemberger \& Gilbert 1987). In at least 2 of these cases, the prey apparently perceived the presence of the predator through polypeptides released by the predator. Several phytoplankton taxa with fixed morphological protuberances have been speculated to function as anti-predation devices, e.g. Ceratium (Hargrave \& Geen 1970, but see Nielsen 1991). Rigid chitan threads, extending from cells of the diatom family Thalassiosiraceae, were shown to reduce their susceptibility to grazing by proto- (Verity \& Villareal 1986) and metazooplankton (Gifford et al. 1981). While effective, some morphologies may not have evolved in response to predation, e.g. mucous sheaths in rotifers (Stemberger \& Gilbert 1987).

Behavioral defenses. Diel vertical migration, whereby zooplankton descend to depth during daylight hours and ascend again to feed during darkness, is often attributed to a behavioral response to predators which hunt by sight (Zaret \& Suffern 1976, Ohman et al. 1983). Direct support for this notion comes from experiments in which the amplitude of migration varied in proportion to predator abundance (Gliwicz 1986) and predation pressure (Bollens \& Frost 1989). The freshwater cladoceran Daphnia also avoids predatory invertebrates by migrating upwards in their presence (Dodson 1988, Ramcharan et al. 1992), while the invertebrates themselves remain at depth during daylight to avoid predation by visually feeding fish (Roth 1968). Provocatively, both marine and freshwater crustacean zooplankton can reverse their migrations in response to surface-feeding predators (Dodson 1988, Ohman 1990), indicating behavioral flexibility rather than strict genetic programming. As observed for the inducible morphological defenses, the behavioral responses appear to be triggered by chemical signals released by feeding predators (Dodson 1988, but see Bollens et al. 1994 for marine copepods). Such antipredator defenses may have costs in terms of reduced nutrition when feeding and defense are both dependent upon motility (Werner \& Hall 1988, Ramcharan et al. 1992). For example, among marine zooplankton, those taxa which are especially visible to fish predators feed primarily at night (Hobson \& Chess 1976).

Behavior such as DVM apparently evolved to minimize encounters with potential predators. Copepods (and presumably other metazooplankton) also have sensors which detect variations in mechanical stimuli, irradiance, and chemical gradients, and these provide defense mechanisms to reduce the probability of capture after encounter. Copepods, especially, are capable of rapid accelerations resulting in short-term swimming speeds of many body lengths per second (Strickler 1975). Their combined perceptive abilities and escape responses function to avoid potential predators which are stationary (Haury et al. 1980), drifting above (Buskey et al. 1986), in pursuit (Singarajah 1969), or are attempting to entrain prey in their flow fields (Trager et al. 1994). Developmental stages as well as adults are capable of escape responses (Yen \& Fields 1992), although the vulnerability to capture varies with prey taxa (Drenner et al. 1978), size and morphology (Confer \& Blades 1975), and developmental stage (Greene \& Landry 1985). Likewise, fish vary in their ability to capture evasive and non-evasive zooplankton (McComas \& Drenner 1982, Vinyard 1982), and some can learn to improve capture efficiency for more evasive prey (Coughlin \& Strickler 1990). Fish and large zooplankton also exhibit complex behaviorally mediated predator avoidance mechanisms, e.g. swarm formation.

Life history strategies. In the enigmatic phytoplankton Phaeocystis (see above) cells form colonies, colonies can increase or decrease in size, and cells can emigrate from colonies (Verity et al. 1988, Cariou et al. 1994), altering the size of Phaeocystis by volume factors of $10^{6}$ to $10^{9}$. While no direct evidence ties life cycle changes to grazing pressure, it is clear that the life history stages of Phaeocystis vary in their susceptibility to grazers and potentially structure the herbivore community (Hansen et al. 1994). Another approach is that of bioluminescent dinoflagellates, whose mechanically stimulated flashes reduce their consumption by copepods (White 1979) and increase predation by fish on the grazing copepods (Abrahams \& Townsend 1993), irrespective of whether bioluminescence actually evolved as an anti-predatory device. A different anti-predation strategy is exhibited by the copepod Diaptomus, which switches from laying subitaneous eggs to diapause eggs coincident with seasonal peaks in predation pressure (Hairston 1987). A further example is the cladoceran Daphnia: in the presence of visually feeding planktivorous fish, which are especially effective at removing larger daphnids, Daphnia increases its intrinsic rate of population growth (Dodson 1989), reduces juvenile length increments, matures earlier, and lays larger clutches of smaller eggs (Machacek 1993); the latter responses are induced by chemicals associated with the predatory fish. In this regard, it may be that trophic cascades are more likely to occur in the freshwater pelagial because Daphnia is 
so often the major herbivore: through parthenogenesis it can reproduce as rapidly as its prey and therefore control their stocks, but its swimming behavior leaves Daphnia particularly susceptible to population decimation by invertebrate and vertebrate predators (Allan 1976, Lynch 1980, Jürgens 1994).

\section{PREDATION AND TROPHIC CASCADES AS STRUCTURAL PRINCIPLES}

We argue that the morphologies and life history strategies of plankton have evolved in relation to their environments. Traditionally, that 'environment' has been considered to be a physical or chemical one, e.g. Margalef (1978) proposed that the functional morphology of phytoplankton is selected by the decay of mechanical energy of water, or turbulence. Kiørboe (1993) argued eloquently that pelagic food web structure is mediated by turbulence and phytoplankton cell size, and that general patterns of mesoscale plankton distributions are consistent with the theoretical bases for such arguments. However, this bottom-up or biogeochemical approach has not proven successful in predicting the timing, magnitude, or temporal dynamics of plankton communities. For example, considerations of fluid dynamics and cell physiology are consistent with the notion that small size is less advantageous to phytoplankton in turbulent waters, but they do not explain the comparative dominance of large cells in such environments, much less the typical dominance of large cells in blooms. Kiørboe (1993) proposed instead that large size provides a refuge from predation, for 2 reasons: the relative abundance of predator to prey decreases as size increases; and the generation times of predators increase more rapidly than those of their prey as size increases, yielding longer lags between phytoplankton growth and zooplankton response. Thus, the risk of being eaten is diminished for larger cells. Banse (1994), too, argued that food web structure cannot be fathomed without equal consideration being given to top-down control.

While the extent of predation between adjacent trophic levels has been the subject of considerable interest (e.g. Sih et al. 1985), here we explore whether the consequences of predation cascade into more distant trophic levels, and the characteristics of predators which are associated with such multi-trophic relationships. This discussion also has implications for the historically different approaches to limnology and oceanography. While biology in the marine pelagial has been pre-occupied with biogeochemical fluxes and stock exploitation, freshwater efforts have been quietly dedicated to deconvolving how lakes and streams work. Hence, the following discussion includes exam- ples from both disciplines, and identifies both similarities and differences between them where evidence warrants

Although it has been common knowledge among farmers and hunters that both resources and predation are important in structuring plant and animal communities, most ecologists prior to 1960 viewed populations as being entirely resource-driven. In that year, Hairston et al. (1960) published their famous 'the world is green' hypothesis. They began with the observation that excessive or widespread destruction of vegetation by grazers is rare, and thus there was an abundant food source available to herbivores. If the grazers were not food-limited, then their abundance must be restricted by predators, preventing the herbivores from depleting their plant resources. Furthermore, since grazers must be predator-limited, their predators must be food-limited. These ideas were developed for terrestrial ecosystems, while aquatic ecosystems were omitted because they are not always 'green' (N. G. Hairston Jr pers. comm.), but the concepts were later adapted to aquatic habitats (Hrbacek 1962, Brooks \& Dodson 1965, Smith 1969, Persson et al. 1992).

The generic form of these hypotheses is that organisms at the top of the food chain are food-limited, and at successively lower levels they are alternately predator- and then food-limited. Changes in food chains with strong trophic links may then 'cascade' from top to bottom (McQueen et al. 1986, 1989, Carpenter et al. 1987). The trophic cascade model predicts that, by their presence or absence, higher trophic levels will determine whether or not conspicuous accumulations of plant biomass will occur at the base of the system. The largest body of evidence supporting the trophic cascade model derives from freshwater habitats (Strong 1992; see McLaren \& Peterson 1994 for a recent terrestrial example). One reason why trophic cascades may be more likely to occur in aquatic than in terrestrial habitats is because water is so much denser than air that plants can be physically supported without having to put the vast majority of their primary production into relatively inedible structural components, as do terrestrial plants. Being small and of high nutritious quality, they can be eaten in their entirety by small grazers, for which prey capture is typically gapelimited (Zaret 1980), leading to a size-structured food chain. Thus, there is little cheating in plankton-based food webs, because predators have to be big enough to eat their prey in its entirety (Hambright et al. 1991), unlike browsing herbivores in terrestrial ecosystems. Hairston \& Hairston (1993) developed this idea further, suggesting that predator:prey size ratios in pelagic systems (where they may be size-dependent; Longhurst 1991) are likely to be substantially larger than those typical of terrestrial ecosystems. 
In the marine pelagial, little attention was given for many years to the possibility that top-down forces might be important. In part, this reflected the biased view of phytoplankton ecologists that production of algal biomass was limited by availability of nutrients or irradiance, and that accumulation of biomass depended only upon the extent of production. This bottom-up or resource interpretation was indirectly supported by the traditional view of marine food chains as diatoms $\rightarrow$ copepods $\rightarrow$ fish (see Kleppel 1993 for origins), because estimates of grazing impact by copepods typically were ca 10 to $50 \%$ of primary production (e.g. Mullin 1969, Kiørboe 1991). This apparent inability to keep pace with algal growth implied that phytoplankton were not grazer-limited and that copepods were not food-limited (Huntley \& Boyd 1984). Studies showing strong dependence of copepod growth upon temperature (Huntley \& Lopez 1992) also implied that food was not limiting.

Since that time, contemporary thinking about plankton community structure has undergone a revolutionary reversal, a change too significant to be merely labelled a new paradigm. In one generation, the hundred year old view that diatoms were the pastures of the sea has been replaced with the notion that much smaller cells are the workhorses in the euphotic zone (Pomeroy 1974), with occasional diatom blooms superimposed on their productivity. It is this microbial food web that tracks changes in controlling physical and chemical processes; diatoms leave and enter the system according to their own unique biology (Smetacek et al. 1990, Lenz 1992). With the recognition of picoand nano-sized autotrophs and mixotrophs came the understanding that small zooplankton were often the dominant herbivores (references in Pierce \& Turner 1992), and estimates of their grazing plus that of larger zooplankton can equal or exceed that of primary production (e.g. Lenz et al. 1993, Verity et al. 1993). The possibility of predator (grazer) control of prey became more distinct, especially given the capabilities for prey selection evidenced by both protoand metazooplankton (Cowles et al. 1988, Verity 1991).

However, there are relatively few instances of actual trophic cascades in marine waters across 3 or more levels (Table 1). Of these, some are direct experimental manipulations, some are merely interpretations of gross patterns in field communities, and some include models of laboratory or field studies. The most compelling evidence suggests that certain plankton food webs may show coupled population oscillations with trophic levels limited alternately by predation and resource availability (e.g. Horsted et al. 1988, Dolan \& Gallegos 1991). Provocatively, fully threequarters of the cascades in Table 1 were initiated by gelatinous predators, which suggests that their ability to rapidly increase population biomass, their high weight-specific ingestion, and/or their large predator: prey size ratios, may be key characteristics in pelagic organisms involved in trophic cascades. It has been argued that trophic cascades are unlikely in the absence of keystone predators (Strong 1992). Alternatively, the common denominator may be moderate-tostrong predation pressure rather than a true keystone predator (Menge et al. 1994). For example, the occurrence of gelatinous carnivores is not always associated with obvious trophic cascades (Purcell et al. 1994).

Only 2 regional assessments of the potential importance of trophic cascades in marine pelagic ecosystems have apparently been published. In both the Baltic Sea and the Chesapeake Bay, USA (Verity 1987, Rudstam et al. 1994), limited evidence suggested that trophic cascades may be seasonally or historically important, but convincing documentation was not available. It has also been argued that trophic cascades may be responsible for patterns in plankton biomass in HNLC (high nutrient low chlorophyll) regimes such as the subarctic

Table 1. Examples of trophic cascades influencing the structure of marine pelagic communities. Mesoz.: mesozooplankton; microz.: microzooplankton; nanoz.. nanozooplankton; phytopl.. phytoplankton

\begin{tabular}{|llll|}
\hline Location & Cascade & Data source & Citation \\
\hline Roskildefjord, Denmark & Sticklebacks $\rightarrow$ Mesoz. $\rightarrow$ Phytopl. & Enclosure & Horsted et al. (1988) \\
Limfjord, Denmark & Mussels $\rightarrow$ Mesoz.Microz. $\rightarrow$ Nanoz. $\rightarrow$ Bacteria & Enclosure & Riemann et al. (1990) \\
Loch Ewe, Scotland & Ctenophore $\rightarrow$ Mesoz. $\rightarrow$ Phytopl. & Enclosure & Gamble et al. (1977) \\
Narragansett Bay, RI, USA & Ctenophores $\rightarrow$ Mesoz. $\rightarrow$ Phytopl. & Enclosure/field & Deason \& Smayda (1982a, b) \\
Rhode River, MD. USA & Rotifers $\rightarrow$ Nanoz $\rightarrow$ Bacteria & Enclosure/model Dolan \& Gallegos (1991) \\
Vancouver Fjord, BC, Canada & Medusae $\rightarrow$ Mesoz. $\rightarrow$ Phytopl. & Field observation Huntley \& Hobson (1978) \\
Kiel Bight, Germany & Medusae $\rightarrow$ Mesoz. $\rightarrow$ Phytopl. & Field observation Moller (1979) \\
North Sea & Euphausids $\rightarrow$ Copepods $\rightarrow$ Phytopl. & Field observation Roff et al. (1988) \\
Gullmar Fjord, Sweden & Medusae $\rightarrow$ Mesoz. $\rightarrow$ Phytopl. & Field observation Lindahl \& Hernroth (1983) \\
Helgoland Bight, Germany & Ctenophore $\rightarrow$ Ctenophore $\rightarrow$ Mesoz. & Field observation Greve \& Reiners (1980) \\
Cheseapeake Bay, USA & Cteno/Medusae $\rightarrow$ Mesoz. $\rightarrow$ Phytopl. & Field/model & Baird \& Ulanowicz (1989) \\
\hline
\end{tabular}


Pacific (Frost 1991), and that recent accidental introductions of ctenophores into the Black Sea have caused significant structural changes (Kideys 1994).

The apparent importance of gelatinous predators in the few reported marine trophic cascades may also reflect on the role of fish in this capacity. While density-dependent competition for food is a general feature of larval and juvenile fish (Valiela 1984), fishery ecologists generally hold that stocks of adult fish are not limited by their resources and thus cannot limit them (Cushing 1975). This conclusion is supported by several typical features of fish populations, including: the lack o: a density-dependent stock-recruitment relationship, the occurrence of strong year classes developing from weak spawning events, and the huge variation in fish recruitment among years with no evidence of simiar variance in prey production. All of these features support the notion that populations of adult fish in the oceans are seldom likely to control the abundance of their prey, in contrast to the evidence from freshwater systems. It has been speculated that fish in the oceans are 10 to 1000 times less abundant than their freshwater counterparts (Horn 1972), perhaps accounting for their apparent lack of predatory impact. If this comparative dilution of fish in the sea is correct, the mechanism would seem to be the huge mortality losses applied primarily during embryonic and larval development.

It may be instructive to consider why trophic cascades appear so well developed in freshwater compared to in marine pelagic ecosystems. An important distinction is that taxonomic diversity of the freshwater pelagial is simplified compared to that of marine waters (Valiela 1984). For example, a variety of herbi-/ omnivores (Lehman 1988) and carnivores (Greene 1985) are missing, including the near-absence of planktonic ambush predators and clupeid-like fishes (Banse 1990). Moreover, feeding at more than one (lower) trophic level may be more extensive in saltwater because of the common importance of mixotrophic ciliates there (Stoecker et al. 1989, Putt 1990); mixotrophic flagellates are well developed in both freshand saltwater (Sanders 1991). In general, mixotrophy appears more important in oligotrophic vs eutrophic waters (Arenovski 1994). If omnivory and generalist feeding are common in marine waters, and if such trophic diversity reduces the likelihood that, e.g. a climatically induced, strong year class of predators would decimate only a single trophic level, then trophic cascades may be minimized there or difficult to validate unequivocably. However, although the success of trophic level manipulation experiments in freshwaters implies that omnivory there is not sufficient to obscure distinctions between trophic levels (Hairston \& Hairston 1993), the converse (that extensive omnivory pre- cludes trophic cascades] is not necessarily true. If cascades are less likely in oligotrophic environments, due to strong substrate control, then the better documentation of cascades in freshwater may reflect the generally more productive trophic status there compared to marine waters (Valiela 1984). Also relevant may be the life history of Daphnia, whose reproductive strategy is designed for rapid colonization and for export to new environments (e.g. by duck's feet), but whose motility behavior prevents it from holding space in the presence of visual planktivores. It is indeed intriguing that the predators most common in marine cascades (jellies) are essentially absent from freshwater, where cascades have been more commonly described, while the freshwater herbivore typically linked to cascades (cladocerans) are unimportant in marine waters.

\section{ROLE OF PHYSICS AND IMPLICATIONS FOR DESIGN OF FUTURE STUDIES}

Ecological communities and physical processes vary in time and space across a broad range of scales (Marine Zooplankton Colloquium 1 1989, Powell 1989). In the ocean, the space-time scales of biology and physics are nearly coincident, so it is likely that their interactions are closely coupled (Steele 1991a). If so, positive correlations might be expected between the variabilities in physical and biological processes (Walsh 1977), although correspondence does not establish cause and effect. Physics and biology are best integrated at mesoscales where biology can be budgeted, e.g. as energy or mass, analogous to the physical laws of conservation of energy, mass, and momentum (Denman \& Powell 1984). At these scales there is good evidence for strong influences by the physics of ocean circulation on the biology of fish and plankton. One example is the close correlation between ocean currents and life cycles of fish such as herring, driven by climatic variations (Steele 1991b). At the population level, this is explained by links between mesoscale mixing and reproductive processes. However, changes at the community level. such as switching between dominance by pelagic versus benthic fish, have not been explained. On the other hand, there is also no indication that dramatic changes in fish stocks (abundance or composition) in such areas as Georges Bank or the North Sea have cascaded down to impact zooplankton (Koslow 1983. I. H. Steele pers. comm.).

The present paper addresses mechanisms whereby individual species, their characteristics, and their interactions contribute to ecosystem structure. Thus, the central question in the context of physics is at what spatial and temporal scales do community parameters become less significant than species attributes (behav- 
ior, morphology, life cycles) in determining apparent success, i.e. standing stocks (Steele 1991a)? While the larger scale physical processes previously discussed also cascade down to the level of the individual, e.g. turbulence effects upon encounter rates (MacKenzie \& Leggett 1991), 'conservation laws for mass, energy, and momentum ... are not sufficient to understand ... competition, predation, species succession and diversity, etc.' (Denman \& Powell 1984, p. 127). Although at larger scales the 'concept of ecological succession ... does not seem appropriate to the changes in marine systems where we explain changing community patterns in a physical context' (Steele 1991a, p. 433), it can also be argued that organisms, especially successful key species, have evolved to take advantage of the higher frequency variability at smaller scales.

Other aspects of physics are relevant to evaluating the role of predation and key species in structuring pelagic ecosystems, and they are advection, dispersal, and patchiness. As discussed in the previous sections, there is sufficient theoretical and experimental evidence to show that predation, morphology, and key species are crucial in structuring marine pelagic communities. However, much of the experimental support derives from contained populations or from descriptive field data, so that the significance of predation-driven forces in open waters remains uncertain. Both supportive and disputive data are available. The major weakness of descriptive data from open waters is that absence of evidence is not evidence of absence. The problem with containment, however, is that enclosures must be sufficiently large to mimic the real world. For example, if they offer no refuges or lack natural feeding guilds to utilize changing resources, then discrepancies will occur between theory and experimental results. Thus, perhaps the ideal environment in which to test these hypotheses is an enclosed body of water with naturally restricted exchange with adjacent waters, e.g. Landry (1978). The ctenophore-zooplankton-phytoplankton cascade observed in Narragansett Bay (Rhode Island, USA; Deason \& Smayda 1982a, b), which has a turnover time of ca $26 \mathrm{~d}$ (Pilson 1985), is perhaps the best example to date.

A related issue is that patchiness, dispersal and advection cause significant sampling artifacts in marine ecosystems. The latter problems are minimized in small lakes, perhaps contributing to better documentation of trophic cascades there, or perhaps simply making cascades more likely to occur; large lakes are more complex (Schelske \& Stoermer 1994). Thus, it is not so much whether predation or trophic cascades structure marine plankton communities, but whether we can provide definitive approaches and methodologies to test competing hypotheses. Top-down forces may not cascade in the pelagial because advective processes act to separate predator and prey before cascades can be complete, i.e. disequilibria, or because seasonal weather patterns 'reset' the system, e.g. Landry (1977). Or perhaps top-down forces may be operating but cannot be confirmed because advection separates us in space from processes in different stages of temporal equilibrium. These sampling issues have long hindered pelagic science, whether chemistry or biology, but in trying to determine the forces structuring an ecosystem, there is an additional, formidable obstacle: trophic identifications for each major taxonomic group are also necessary. Some techniques have been developed to sample over large spatial and temporal scales, to minimize problems of sampling statistics. For example, acoustics can be used for fish stock assessment over large scales; but can the return echoes distinguish a planktivore from a primary carnivore from a secondary consumer? The crux of the problem is the extent to which we are comfortable trading realism for analytical accuracy: our conceptual models and scientific methods must necessarily be 'a judiciously chosen set of lies, or perhaps more accurately put, partial truths about reality, which have been chosen to permit us to reason more effectively about some issue than we otherwise could' (Baumol 1984).

Let us assume for the moment that one has carefully designed an experimental test, and sampling was spatially and temporally complete. Do complications exist which could impede interpretation of the data? Evidence from both freshwater and marine habitats suggests that several factors may obfuscate data analysis. For example, predator-induced effects may occur but may not be evident as changes in population abundance or as bulk removal. Rather, the affected populations may alter patterns in vertical distribution or migration (Rudstam et al. 1994), the taxonomic composition of a trophic level may change (McCauley \& Briand 1979), or its size structure (Hrbacek 1962). As such, food webs may not collapse clearly into food chains. Moreover, 'tangles in trophic architecture' (Strong 1992) (i.e. omnivory, mixotrophy, substitutability of species, compensation among taxa for functions of others, inedibility, mobility and defenses) may prevent the occurrence of key species upon which sustained consumption can more clearly take its toll. Topdown and bottom-up regulation can be additive, for example, starving fish larvae may be more susceptible to predation, or both forces can be (differentially) influenced by the same abiotic factors, e.g. increased irradiance stimulates both primary production and visual predation (Aksnes \& Giske 1993). Conversely, relationships between trophic levels may be non-linear (Dwyer \& Perez 1983), non-additive (Stoecker \& Evans 1985) or exhibit threshold dynamics: predation impact upon a prey population may be sustainable up to a cer- 
tain point, beyond which drastic declines in prey abundance occur. If ontogenetic changes (e.g. dietary) or time lags between prey consumption and predator reproduction occur, top-down effects may be obscured (Power 1992). Finally, physical processes on long time scales may dominate shorter frequency biological interactions (Aebischer et al. 1990), so that any topdown effects are muted or invisible.

\section{CLOSING THOUGHTS}

Theory is rather explicit about the conditions under which resource availability and predation should dominate trophic interactions. On the other hand, the real world is seldom as simple as theoretical boundary conditions (Pimm 1992). Research during the past $50 \mathrm{yr}$ has shown that not all plants are equally edible, not all herbivores are equally effective, not all predators are equally proficient, and not all environments are equally hospitable (Hunter \& Price 1992). The considerations in this paper illustrate that it can be simpler to construct pragmatic post hoc explanations for observed patterns in trophic structure than it can be to devise sound theoretical underpinning.

We propose that biogeochemical fluxes are spearheaded by key taxa, perhaps even 'keystone species' (sensu Bond 1993) whose environmental adaptations, whether through behavior, morphology, physiology, or life history, are so strong that they direct trophic relations. Some specific examples were postulated in the section on life histories and morphologies. We have argued that dominant species in the marine pelagial attain their status as much by reducing mortality due to predation as by increasing growth or reproductive rates. While it can still be instructive to ask whether top-down or bottom-up forces regulate community structure, because the regulatory mechanisms are distinctly different, we suggest a new synthetic focus: 'How does the pelagic environment select for life histories, morphologies, and behaviors of organisms under conditions when food availability and predation both affect trophic interactions?' In our rush to get into explanatory modelling, planktologists have trodden on the species and stuffed them into trophic boxes, pyramids or size fraction relationships. The underlying assumption has been that the categories comprise homogeneous units. Recent work is leading to differentiation and also to expansion of our knowledge of pelagic system structure and its shaping forces: picoplankton and protozoa of the 1980s are now extended into viruses and parasitoids. At the same time, groupspecific differences in behavior are coming to light that make it necessary to discriminate smaller constituents within the tidy boxes: compare Longhurst's (1991) box model with that of Steele (1974). We now advocate opening the boxes, taking out the dominant species and studying them at their relevant levels of selection (e.g. predator avoidance, life cycle strategy) and not just growth physiology (ICES 1994).

This proposal has implications for contemporary ocean science, which is being increasingly focused on large-scale, interdisciplinary programs. Some of these are designed to derive horizontal or vertical fluxes of elements which have anthropogenic or geochemical significance, e.g. the carbon-based Joint Global Ocean Flux Study (JGOFS). Others concentrate on establishing the linkages between predator and prey, and their relation to physics, in order to describe ecosystem function, e.g. Global Ocean Ecosystem Dynamics (GLOBEC). The paths are distinctly different, yet the long-term objectives are identical: an improved mechanistic understanding of ocean dynamics and the ability to predict future changes. The inescapable conclusion from the present analysis is that attempts to identify the forces structuring the marine pelagial must be specifically designed to address that question, i.e. organism-organism and organism-environment interactions, and not to measure carbon fluxes. This is simply because adaptation and selection operate at the species level. But the connection between organismand element-driven oceanography is that the transfer of elements or energy through the system depends upon trophic structure and activity (Hairston \& Hairston 1993): the composition of the biological pump determines its efficiency of operation. One can no more predict carbon fluxes without a mechanistic understanding of ecosystem structure than one can deconvolve the mechanisms from flux measurements alone: flux estimates cannot predict whether sardines vs anchovies, or herring vs mackerel, will dominate, but evidence does suggest that species determine fluxes. A study could be envisioned where both approaches are applied concurrently: thus, the thermodynamic constraints on the system (e.g. light field) could be derived from measurement of total community metabolism or throughput. The deviation of in situ instantaneous rates from theoretical maxima indicate the 'state' of the system and would be necessary to define the units in structural terms; i.e. how much of the energy is diverted to deterrents or flight muscle and how much to reproduction of DNA supporting living plasma. Only by combining the 2 approaches will we ever understand how pelagic environments select their inhabitants and how the inhabitants determine energy flow and material fluxes.

Banse (1994) argued insightfully that in regard to more realistic modeling of food webs .. we are short on explicit theory, not only for marine and freshwater systems, but also for ecology in general'. He, too, pro- 
posed that research should focus on the biology of key species, but did not believe that scientists and funding agencies would support endless autecological investigations. The avenues we suggest here are not to concentrate so much on metabolic assessments or to search for minutiae, which are unlikely to differ much among species, but to identify critical aspects of life history, morphology, or behavior. These should be examined in the context of rigorous testing of explicit hypotheses. For too long we have shied from playing Pandora, that is, harnessing courage to curiosity. By studying individual species in greater detail, we will be able to understand the shaping forces of the abiotic environment on the one hand, and biotic interactions, including competition and predation, on the other. In answering this question we can truly integrate ecological concepts with predictive models, and make significant purchase in our climb toward understanding pelagic processes.

Acknowledgements. The musings in this paper were stimulated into definable form by invitations from P. LeB. Williams to present opposing views in the argument over predation vs resource limitation as structural edifices supporting marine plankton communities, as part of a workshop in November 1993 planning the evolution of a new research program in the U.K., 'Plankton Reactivity in the Marine Environment' (PRIME). Further refined concepts were presented at the ICES Symposium on Zooplankton Production convened in Plymouth, England, in August 1994. We thank the PRIME and ICES steering committees for their support and encouragement, especially the late J C. Gamble, and R. P. Harris, T Kiorboe, J. H. Steele, and P. LeB. Williams. Travel support was provided by the U.K. National Environment Research Council and the U.S. National Science Foundation. The opportunity to ruminate on these ideas would not have been possible without salary support provided by U.S. DOE grant FG0292ER61419, NSF grant OCE-90-22318, and the Skidaway Institute of Oceanography. Numerous colleagues promoted this effort and offered valuable advice and insights, including $K$. G. Banse, J. Dolan, W. Greve, N. G. Hairston Jr., R. Hopcroft, P. Kremer, J. Lenz, G.-A. Paffenhöfer, J. C. Roff, J. H. Steele, J. T Turner, and 2 anonymous reviewers. Ideas are of little use if everyone agrees with them. This paper is offered in the hope that imagination and knowledge are equal partners in the pursuit of understanding marine pelagic ecosystems. This publication is no. 942 of the Alfred Wegener Institute for Polar and Marine Research and no. 6 of PRIME.

\section{LITERATURE CITED}

Abrahams MV, Townsend LD (1993) Bioluminescence in dinoflagellates: a test of the burglar alarm hypothesis. Ecology 74:258-260

Aebischer NJ, Coulson JC, Colebrook JM (1990) Parallel long-term trends across four marine trophic levels and weather. Nature 347:753-755

Aksnes DL, Giske J (1993) A theoretical model of aquatic visual feeding. Ecol Model 67:233-250

Allan JD (1976) Life history patterns in zooplankton. Am Nat $110: 165-180$
Arenovski AL (1994) Distribution, abundance, and ecology of mixotrophic algae in marine and freshwater plankton communities. PhD thesis, Massachusetts Institute of Technology/Woods Hole Oceanographic Institute, Cambridge and Woods Hole, WHOI-94-22

Baird D, Ulanowicz RE (1989) The seasonal dynamics of the Chesapeake Bay ecosystem. Ecol Monogr 59:329-364

Banse K (1990) On pelagic food web interactions in large water bodies. In: Tilzer MM, Serruya C (eds) Large lakes. Ecological structure and function. Springer-Verlag, New York, p 556-579

Banse K (1994) Grazing and zooplankton production as key controls of phytoplankton production in the open ocean. Oceanography 7:13-20

Barker GLA, Hayes PK, Medlin LK (1994) Preliminary results using the RAPD analysis as a means of screening populations during the development of natural blooms and mesocosm blooms of the prymnesiophyte, Emiliania. Sarsia 79:301-306

Bathmann U, Smetacek V, de Baar H, Fahrbach E, Krause G (1994) The expeditions Antarktis X/6-8 of R/V 'Polarstern' in 1992/93. Ber Polarforsch 135:235

Baumann MEM, Lancelot C, Brandini FP, Sakshaug E, John DM (1994) The taxonomic identity of the cosmopolitan prymnesiophyte Phaeocystis: a morphological and ecophysiological approach. J mar Syst 5:5-22

Baumol WJ (1984) On my attitudes: sociopolitical and methodological. Am Econ 28:5-9

Berge G (1962) Discoloration of the sea due to Coccolithus huxleyi 'bloom'. Sarsia 6:27-40

Bollens SM, Frost BW (1989) Predator-induced diel vertical migration in a marine planktonic copepod. J Plankton Res 11:1047-1065

Bollens SM, Frost BW, Cordell JR (1994) Chemical, mechanical, and visual cues in the vertical migration of the marine planktonic copepod Acartia hudsonica. J Plankton Res 16: $555-564$

Bond WJ (1993) Keystone species. In: Schulze ED, Mooney HA (eds) Biodiversity and ecosystem function. SpringerVerlag, New York, p $237-253$

Bone $Q$ (1978) Locomotor muscle. In: Hoar WS, Randall DJ (eds) Fish physiology, Vol 7, Locomotion. Academic Press, New York, p 361-424

Bratbak G, Egge JK. Heldal M (1993) Viral mortality of the marine alga Emiliania huxleyi (Haptophyceae) and termination of algal blooms. Mar Ecol Prog Ser 93:39-48

Brooks JL, Dodson SI (1965) Predation, body size, and composition of plankton. Science 150:28-35

Brown CW, Yoder JA (1994) Coccolithophorid blooms in the global ocean. J geophys Res 99:7467-7482

Bucklin A, Frost BW, Kocher TD (1995) Molecular systematics of 6 Calanus and 3 Metridia species (Calanoida, Copepoda). Mar Biol 121:655-664

Bühler $H$ (1930) Die Verdauungsorgane der Stromateidae (Teleost). Z Morph Ökol Tiere 19:59-115

Bundy $\mathrm{MH}$, Paffenhöfer GA (1993) Innervation of copepod antennules investigated using laser scanning confocal microscopy. Mar Ecol Prog Ser 102:1-14

Burckle LH, Cirilli J (1987) Origin of the diatom ooze belt in the Southern Ocean: implications for late Quaternary paleoceanography. Micropaleontology 33:82-86

Buskey EJ, Mann CG, Swift E (1986) The shadow response of the estuarine copepod Acartia tonsa (Dana). J exp mar Biol Ecol 103:65-75

Butler NM, Suttle CA, Neill WE (1989) Discrimination by freshwater zooplankton between single algal cells differing in nutritional status. Oecologia 78:368-372 
Cariou V, Casotti R, Birrien JL, Valout D (1994) The initiation of Phaeocystis colonies. J Plankton Res 16:457-470

Carmichael WW (1986) Algal toxins. Adv bot Res 12:47-101 Carpenter SR, Kitchell JF, Hodgson JR, Cochran PA, Elser J.J, Elser MM, Lodge DM, Kretchmer D. He X, von Ende CN (1987) Regulation of lake primary productivity by food web structure. Ecology 68:1863-1876

Coley PD, Bryant JP, Chapin FS III (1985) Resource availability and plant antiherbivore defense. Science 230:895-899

Confer JL, Blades PI (1975) Omnivorous zooplankton and planktivorous fish. Limnol Oceanogr 20:571-579

Coughlin DJ, Strickler JR (1990) Zooplankton capture by coral reef fish: an adaptive response to evasive prey. Environ Biol Fish 29:35-42

Cowles TJ, Olson RJ, Chisholm SW (1988) Food selection by copepods: discrimination on the basis of food quality. Mar Biol 100:41-49

Cushing DH (1975) Marine ecology and fisheries. Cambridge Univ Press, Cambridge

Dawkins R (1987) The blind watchmaker. WW Norton \& Co, New York

Deason EE, Smayda TJ (1982a) Ctenophore-zooplanktonphytoplankton interactions in Narragansett Bay, Rhode Island, USA, during 1972-1977. J Plankton Res 4: $203-217$

Deason EE, Smayda TJ (1982b) Experimental evaluation of herbivory in the ctenophore Mnemiopsis leidyi relevant to ctenophore-zooplankton-phytoplankton interactions in Narragansett Bay, Rhode Island, USA. J Plankton Res 4 : $219-236$

Denman KL, Powell TM (1984) Effects of physical processes on planktonic ecosystems in the coastal ocean. Oceanogr mar Biol A Rev 22:125-168

Dodson SI (1988) The ecological role of chemical stimuli for the zooplankton: predator avoidance behavior in Daphnia. Limnol Oceanogr 33:1431-1439

Dodson SI (1989) The ecological role of chemical stimuli for the zooplankton: predator-induced morphology in Daphnia. Oecologia 78:361-367

Dolan JR, Gallegos CL (1991) Trophic coupling of rotifers, microflagellates, and bacteria during fall months in the Rhode River Estuary. Mar Ecol Prog Ser 77:147-156

Drenner RW, Strickler JR, O'Brien WJ (1978) Capture probability: the role of zooplankter escape in the selective feeding of planktivorous fish. J Fish Res Bd Can 35: $1370-1373$

Driedzic WR, Hochachka PW (1978) Metabolism in fish during exercise. In: Hoar WS, Randall DJ (eds) Fish physiology, Vol VII. Academic Press, New York, p 503-543

Dwyer RL, Perez KT (1983) An experimental examination of ecosystem linearization. Am Nat 121:305-323

Ehrlich PR, Raven PH (1964) Butterflies and plants: a study in coevolution. Evolution 18:586-608

Emiliani C (1993) Viral extinctions in deep sea species. Nature 366:217-218

Faulkner DJ (1984) Marine natural products: metabolites of marine algae and herbivorous marine molluscs. Nat Prod Rep 1:251-280

Frost BW (1991) The role of grazing in nutrient-rich areas of the open sea. Limnol Oceanogr 36:1616-1630

Fulton RS III, Paerl HW (1987) Toxic and inhibitory effects of the blue-green alga Microcystis aeruginosa on herbivorous zooplankton. J Plankton Res 9:837-855

Gamble JC, Davies JM, Steele JH (1977) Loch Ewe bag experiment, 1974. Bull mar Sci 27:146-175

Gifford DJ, Bohrer RW, Boyd CM (1981) Spines on diatoms do copepods care? Limnol Oceanogr 26:1057-1062
Gill CW, Crisp DJ (1985) Sensitivity of intact and antennuleamputated copepods to water disturbance. Mar Ecol Prog Ser 21:221-227

Gliwicz MZ (1986) Predation and the evolution of vertical migration in zooplankton. Nature 320:746-748

Greene CH (1985) Planktivore functional groups and patterns of prey selection in pelagic communities. J Plankton Res 7 : $35-40$

Greene CH, Landry MR (1985) Patterns of prey selection in the cruising calanoid predator Euchaeta elongata. Ecology 66:1408-1416

Greve W, Reiners F (1980) The impact of prey-predator waves from estuaries on the planktonic marine ecosystem. In: Kennedy VS (ed) Estuarine perspectives. Academic Press, New York, p 405-421

Hairston NG Jr (1987) Diapause as a predator-avoidance adaptation. In: Kerfoot WC, Sih A (eds) Predation. Univ Press of New England, Hanover, $\mathrm{NH}_{1}$ p 281-290

Hairston NG Jr, Hairston NG Sr (1993) Cause-effect relationships in energy flow, trophic structure, and interspecific interactions. Am Nat 142:379-411

Hairston NG Sr, Smith FE, Slobodkin LB (1960) Community structure, population control, and competition. Am Nat 94 : $421-425$

Hambright KD, Drenner RW, McComas SR, Hairston NG Jr (1991) Gape-limited piscivores, planktivore size refuges, and the trophic cascade hypothesis. Arch Hydrobiol 121: $389-404$

Hansen $B$, Verity $P$, Falkenhaug $T$, Tande $K S$, Norrbin F (1994) On the trophic fate of Phaeocystis pouchetii (Harriot). V. Trophic relationships between Phaeocystis and zooplankton: an assessment of methods and size dependence. J Plankton Res 16:487-511

Hansen FC, Reckermann Mi Klein Breteler WCM, Riegman R (1993) Phaeocystis blooming enhanced by copepod predation on protozod: evidence from incubation experiments. Mar Ecol Prog Ser 102:51-57

Hardy AC (1956) The open sea, its natural history, Part 1, The world of plankton. Houghton Mifflin, Boston

Hargrave BT, Geen GH (1970) Effects of copepod grazing on two natural phytoplankton populations. J Fish Res Bd Can 27:1395-1403

Haury LR, Kenyon DE, Brooks JR (1980) Experimental evaluation of the avoidance reaction of Calanus finmarchicus. J Plankton Res 2:187-202

Havel JE (1987) Predator-induced defenses: a review. In: Kerfoot WC, Sih A (eds) Predation. Univ Press of New England, Hanover, $\mathrm{NH}, \mathrm{p} 263-278$

Hay ME, Fenical W (1988) Marine plant-herbıvore interactions: the ecology of chemical defense. A Rev Ecol Syst 19: $111-145$

Hays GC, Proctor CA, John AWG, Warner A.J (1994) Interspecific differences in the diel vertical migration of marine copepods: the implications of size, color, and morphology. Limnol Oceanogr 39:1621-1629

Hertz PE, Huey RB, Garland T Jr (1988) Time budgets, thermoregulation, and maximal locomotor performance: are reptiles Olympians or Boy Scouts? Am Zool 28: $927-938$

Hessen DO, van Donk E (1993) Morphological changes in Scenedesmus induced by substances released from Daphnia. Arch Hydrobiol 127:129-140

Hobson ES, Chess JR (1976) Trophic interactions among fish and zooplankters near shore at Santa Catalina Island, California. Fish Bull US 74:567-598

Horn MH (1972) The amount of space available for marine and freshwater fishes. Fish Bull US 70:1295-1298 
Horsted SJ, Nielsen TG, Riemann B, Pock-Steen J, Bjørnsen PK (1988) Regulation of zooplankton by suspension-feeding bivalves and fish in estuarine enclosures. Mar Ecol Prog Ser 48:217-224

Hrbacek J (1962) Species composition and the amount of zooplankton in relation to the fish stock. Rozpr Cesk Akad Ved, Rada Mat Prir Ved 72:1-116

Hunter MD, Price PW (1992) Playing chutes and ladders: heterogeneity and the relative roles of bottom-up and topdown forces in natural communities. Ecology 73:724-732

Huntley ME, Boyd C (1984) Food-limited growth of marine zooplankton. Am Nat 124:455-478

Huntley ME, Hobson LA (1978) Medusa predation and plankton dynamics in a temperate fjord, British Columbia. J Fish Res Bd Can 35:257-261

Huntley ME, Lopez MDG (1992) Temperature-dependent production of marine copepods: a global synthesis. Am Nat 140:201-242

Huntley ME, Nordhausen W, Lopez MDG (1994) Elemental composition, metabolic activity and growth of Antarctic krill Euphausia superba during winter. Mar Ecol Prog Ser 107:23-40

Huntley ME, Sykes P, Rohan S, Marin V (1986) Chemicallymediated rejection of dinoflagellate prey by the copepods Calanus pacificus and Paracalanus parvus: mechanism, occurrence, and significance. Mar Ecol Prog Ser 28:105-120

ICES (1994) Report of the workshop on the trans-latitudinal study of Calanus finmarchicus in the North Atlantic. Comm Meet int Counc Explor Sea CM-ICES 1994/L:10

Ikeda T, Dixon P (1982) Body shrinkage as a possible overwintering mechanism of the Antarctic krill Euphausia superba Dana. J exp mar Biol Ecol 62:143-151

Jungmann D, Henning M, Juttner F (1991) Are the same compounds in Microcystis responsible for toxicity to Daphnia and inhibition of its filtering rate? Int Rev ges Hydrobiol $76: 47-56$

Jürgens K (1994) Impact of Daphnia on planktonic microbial food webs - a review. Mar microb Food Webs 8:295-324

Jürgens K, Gude $H$ (1994) The potential importance of grazing-resistant bacteria in planktonic ecosystems. Mar Ecol Prog Ser 112:169-188

Kashkin NI (1963) Materials on the ecology of Phaeocystis pouchetii (Hariot) Lagerheim 1893 (Chrysophyceae). II. Habitat and specification of biogeographical characteristics. Okeanologiya 3:697-705 (in Russian)

Kerfoot WC, Sih A (1987) Predation - direct and indirect impacts on aquatic communities. Univ Press of New England, Hanover, $\mathrm{NH}$

Kideys AE (1994) Recent dramatic changes in the Black Sea ecosystem: the reason for the sharp decline in Turkish anchovy fisheries. J mar Syst 5:171-181

Kils $U$ (1990) On the microstructure of microlayers: results of an in situ zooplankton counter. EOS 71:94

Kiørboe T (1991) Pelagic fisheries and spatio-temporal variability in zooplankton productivity. Proc 4 th Conf Copepoda. Bull Plankton Soc Japan Spec Vol: 229-249

Kiørboe T (1993) Turbulence, phytoplankton cell size, and the structure of pelagic food webs. Adv mar Biol 29:1-72

Kitchell JF, Carpenter SR (1987) Piscivores, planktivores, fossils, and phorbins. In: Kerfoot WC, Sih A (eds) Predation. Univ Press of New England, Hanover, NH, p 132-146

Kleppel GS (1993) On the diets of calanoid copepods. Mar Ecol Prog Ser 99:183-195

Knox G (1994) The biology of the Southern Ocean. Cambridge Univ Press, Cambridge

Konchina YV (1991) Trophic status of Peruvian fisheries in South Pacific oceanic ecosystems. In: International Sym- posium on Benguela Trophic Functioning, Univ of Cape Town, Sept 1991. Univ of Cape Town, Cape Town, p 74

Kornmann P (1955) Beobachtungen an Phaeocystis-Kulturen Helgoländer wiss Meeresunters 5:218-233

Koslow JA (1983) Zooplankton community structure in the North Sea and Northeast Atlantic: development and test of a biological model. Can J Fish Aquat Sci 40:1912-1924

Kuhlmann HW, Heckmann K (1985) Interspecific morphogens regulating predator-prey relationships in protozoa. Science 227:1347-1349

Lampert W (1987) Feeding and nutrition in Daphnia. In: Peters RH, de Bernardi R (eds) Daphnia. Mem Ist Ital Idrobiol 45:143-192

Lampert W, Rothhaupt KO, von Elert E (1994) Chemical induction of colony formation in a green alga (Scenedesmus acutus) by grazers (Daphnia). Limnol Oceanogr 39:1543-1550

Landry MR (1977) A review of important concepts in the trophic organization of pelagic ecosystems. Helgoländer wiss Meeresunters 30:8-17

Landry MR (1978) Population dynamics and production of a planktonic marine copepod, Acartia clausii, in a small temperate lagoon on San Juan Island, Washington. Int Rev ges Hydrobiol 63:77-119

Ledford-Hoffman PA, DeMaster DJ, Nittrouer CA (1986) Biogenic silica in the Ross Sea and the importance of Antarctic continental shelf deposits in the marine silica budget Geochim cosmochim Acta 50:2099-2110

Lehman JT (1988) Ecological principles affecting community structure and secondary production by zooplankton in marine and freshwater environments. Limnol Oceanogr 33(part 2):931-945

Lenz J (1992) Microbial loop, microbial food web, and classical food chain: their significance in pelagic marine ecosystems. Arch Hydrobiol Beih Ergeb Limnol 37:265-278

Lenz J, Morales A, Gunkel J (1993) Mesozooplankton standing stock during the North Atlantic spring bloom study in 1989 and its potential grazing pressure on phytoplankton: a comparison between low, medium, and high latitudes. Deep Sea Res II 40:559-572

Lewis WM Jr (1986) Evolutionary interpretations of allelochemical interactions in phytoplankton algae. Am Nat 127:184-194

Lindahl O, Hernroth L (1983) Phyto-zooplankton community in coastal waters of western Sweden - an ecosystem off balance? Mar Ecol Prog Ser 10:119-126

Liss PS, Malin G, Turner SM, Holligan PM (1994) Dimethyl sulphide and Phaeocystis: a review. J mar Syst 5:41-53

Longhurst AR (1991) Role of the marine biosphere in the global carbon cycle. Limnol Oceanogr 36:1507-1526

Longhurst AR, Harrison WG (1989) The biological pump: profiles of plankton production and consumption in the upper ocean. Prog Oceanogr 22:47-123

Lynch $M$ (1980) The evolution of cladoceran life histories. Q Rev Biol 55:23-42

Machacek J (1993) Comparison of the response of Daphnia galeata and Daphnia obtusa to fish-produced chemical substance. Limnol Oceanogr 38:1544-1550

MacKenzie BR, Leggett WC (1991) Quantifying the contribution of small-scale turbulence to the encounter rates between larval fish and their zooplankton prey: effects of wind and tide. Mar Ecol Prog Ser 73:149-160

Malej A, Harris RP (1993) Inhibition of copepod grazing by diatom exudates: a factor in the development of mucus aggregates? Mar Ecol Prog Ser 96:33-42

Margalef R (1978) Life forms of phytoplankton as survival alternatives in an unstable envir onment. Oceanol Acta 1:493-510 
Marine Zooplankton Colloquium 1 (1989) Future marine zooplankton research -- a perspective. Mar Ecol Prog Ser 55: $197-206$

Marschall HP (1988) The overwintering strategy of Antarctic krill under the pack ice of the Weddell Sea. Polar Biol 9: $129-135$

McCauley E, Briand F (1979) Zooplankton grazing and phytoplankton species richness: field tests of the predation hypothesis. Limnol Oceanogr 24:243-252

McComas SR, Drenner RW (1982) Species replacement in a reservoir fish community: silverside feeding mechanics and competition. Can J Fish Aquat Sci 39:815-821

McLaren BE, Peterson RO (1994) Wolves, moose, and tree rings on Isle Royale. Science 266:1555-1558

McQueen DJ, Johannes MRS, Post JR, Stewart TJ, Lean DRS (1989) Bottom-up and top-down impacts on freshwater pelagic community structure. Ecol Monogr 59: 289-309

McQueen DJ, Post JR, Mills EL (1986) Trophic relationships in freshwater pelagic ecosystems. Can J Fish Aquat Sci 43: $1571-1581$

Medlin LK, Lange M, Baumann MEM (1994) Genetic differentiation among three colony-forming species of Phaeocystis: further evidence for the phylogeny of the Prymnesiophyta. Phycologia 33:199-212

Menge BA, Berlow EL, Blanchette CA, Navarette SA, Yamada SB (1994) The keystone species concept: variation in interaction strength in a rocky intertidal habitat Ecol Monogr 64:249-286

Möller H (1979) Significance of coelenterates in relation to other plankton organisms. Meeresforsch 27:1-18

Mullin MM (1969) Production of zooplankton in the ocean: the present status and problems. Oceanogr mar Biol A Rev $7: 293-314$

Nielsen TG (1991) Contribution of zooplankton grazing to the decline of a Ceratium bloom. Limnol Oceanogr 36 $1091-1106$

Ohman MD (1990) The demographic benefits of diel vertical migration by zooplankton. Ecol Monogr 60:257-281

Ohman MD, Frost BW, Cohen EB (1983) Reverse diel vertical migration: an escape from invertebrate predators. Science $220: 1404-1407$

Paffenhöer GA (1988) Feeding rates and behavior of zooplankton. Bull mar Sci 43:430-445

Paffenhöfer GA, Lewis KD (1990) Perceptive performance and feeding behavior of calanoid copepods. J Plankton Res 12:933-946

Persson L, Diehl S, Johansson L, Andersson G, Hamrin SF (1992) Trophic interactions in temperate lake ecosystems: a test of food chain theory. Am Nat 140:59-84

Pierce RW, Turner JT (1992) Ecology of planktonic ciliates in marine food webs. Rev aquat Sci 6:139-181

Pilson MEQ (1985) On the residence time of water in Narragansett Bay. Estuaries 8:2-14

Pimm SL (1992) Frog ponds and ocean iron. Nature 360 $298-299$

Pomeroy LR (1974) The ocean's food web: a changing paradigm. BioSci 24:542-544

Poulet SA, Ianora A, Miralto A, Meijer L (1994) Do diatoms arrest embryonic development in copepods? Mar Ecol Prog Ser 111:79-86

Powell TM (1989) Physical and biological scales of variability in lakes, estuaries, and the coastal ocean. In: Roughgarden J, May R, Levin S (eds) Perspectives in ecological theory. Princeton Univ Press, Princeton, p 157-176

Power ME (1992) Top-down and bottom-up forces in food webs: do plants have primacy? Ecology 73:733-746
Purcell JE, White JR, Roman MR (1994) Predation by gelatinous zooplankton and resource limitation as potential controls of Acartia tonsa copepod populations in Chesapeake Bay. Limnol Oceanogr 39:263-278

Putt M (1990) Abundance, chlorophyll content, and photosynthetic rates of ciliates in the Nordic Seas during summer Deep Sea Res 37:1713-1731

Ramcharan CW, Dodson SI, Lee J (1992) Predation risk, prey behavior, and feeding rate in Daphnia pulex. Can J Fish Aquat Sci 49:159-165

Riemann B, Sørensen HM, Biernsen PK, Horsted SJ, Jensen LM, Nielsen TG, Sondergaard M (1990) Carbon budgets of the microbial food web in estuarine enclosures. Mar Ecol Prog Ser 65:159-170

Roff JC, Middlebrook K, Evans F (1988) Long-term variability in North Sea zooplankton off the Northumberland coast: productivity of small copepods and analysis of trophic interactions. J mar biol Ass UK 68:143-164

Roth JC (1968) Benthic and limnetic distribution of three Chaoborous species in a southern Michigan lake (Diptera, Chaoboridael. Limnol Oceanogr 13:242-249

Rousseau V, Vaulot D, Casotti R, Cariou V, Lenz J, Gunkel J, Baumann M (1994) The life cycle of Phaeocystis (Prymnesiophyceae): evidence and hypotheses. J mar Syst 5:23-39

Rudstam LG, Aneer G. Hilden M (1994) Top-down control in the pelagic Baltic ecosystem. Dana 10:105-129

Runge JA, Pepin P, Silvert W (1987) Feeding behavior of the Atlantic mackerel Scomber scombrus on the hydromedusa Aglantha digitale. Mar Biol 94:329-333

Sanders RW (1991) Mixotrophic protists in marine and freshwater ecosystems. J Protozool 38:76-81

Schelske CL, Stoermer EF (1994) Did top-down effects amplify anthropogenic nutrient perturbations in Lake Michigan? Comment on Evans (1992). Can J Fish Aquat Sci 51: $2147-2149$

Schultz JC (1988) Many factors influence the evolution of herbivore diets, but plant chemistry is central. Ecology 69: $896-897$

Sieracki ME, Verity PG, Stoecker DK (1993) Plankton community response to sequential silicate and nitrate depletion during the 1989 North Atlantic spring bloom. Deep Sea Res II 40:213-226

Signor PW, Vermeij GJ (1994) The plankton and the benthos origins and early history of an evolving relationship. Paleobiology 20:297-319

Sih A (1987) Predators and prey lifestyles: an evolutionary and ecological overview. In: Kerfoot WC, Sih A (eds) Predation. Univ Press of New England, Hanover, NH, p 203-224

Sih A, Crowley P, McPeek M, Petranka J, Strohmeier K (1985) Predation, competition, and prey communities: a review of field experiments. A Rev Ecol Syst 16:269-311

Singarajah KV (1969) Escape reactions of zooplankton: the avoidance of a pursuing siphon tube. $J$ exp mar Biol Ecol 3: $171-178$

Smetacek V (1985) The annual cycle of Kiel Bight plankton: a long-term analysis. Estuaries 8:145-157

Smetacek V, Scharek R, Nothig EM (1990) Seasonal and regional variation in the pelagial and its relationship to the life history of krill. In: Kerry KR, Hempel G (eds) Antarctic ecosystems. Springer-Verlag, Berlin, p 103-114

Smith FE (1969) Effects of enrichment in mathematical models. In: Eutrophication: causes, consequences, correctives. National Academy of Science, Washington, DC, p $631-645$

Smith SL, Schnack-Schiel S (1990) Polar zooplankton. In: Smith WO Jr (ed) Polar oceanography, Part B. Academic Press, San Diego, CA, p 527-598 
Smith WO Jr, Codispoti LA, Nelson DM, Manley T, Buskey EJ Jr, Niebauer HJ, Cota GF (1991) Importance of Phaeocystis blooms in the high-latitude ocean carbon cycle. Nature 352:514-516

Steele JH (1974) The structure of marine ecosystems. Harvard Univ Press, Cambridge

Steele JH (1991a) Can ecological theory cross the land-sea boundary? J theor Biol 153:425-436

Steele JH (1991b) Marine functional diversity. BioSci 41: $470-474$

Stefels J, van Boekel WHM (1993) Production of DMS from dissolved DMSP in axenic cultures of the marine phytoplankton species Phaeocystissp. Mar Ecol Prog Ser 97:11-18

Steinberg DK, Silver MW, Pilskaln $\mathrm{CH}$, Coale SL, Paduan JB (1994) Midwater zooplankton communities on pelagic detritus (giant larvacean houses) in Monterey Bay, California. Limnol Oceanogr 39:1606-1620

Stemberger RS, Gilbert JJ (1987) Defenses of planktonic rotifers against predators. In: Kerfoot WC, Sih A (eds) Predation. Univ Press of New England, Hanover, NH, p 227-239

Stoecker DK, Evans GT (1985) Effects of protozoan herbivory and carnivory in a microplankton food web. Mar Ecol Prog Ser 25:159-167

Stoecker DK, Taniguchi A, Michaels AE, Davis LH (1989) Abundance of autotrophic, mixotrophic, and heterotrophic planktonic ciliates in shelf and slope waters. Mar Ecol Prog Ser 50:241-254

Strickler JR (1975) Swimming of planktonic Cyclops species (Copepoda, Crustacea): pattern, movements, and their control. In: Wu TYT, Brokaw CJ, Brennan C (eds) Swimming and flying in nature, Vol 2. Plenum Press, New York, p 599-613

Strong DR Jr (1992) Are trophic cascades all wet: differentiation and donor control in speciose ecosystems. Ecology 73: $747-754$

Strong DR Jr, Lawton JH, Southwood TRE (1984) Insects on plants: community patterns and mechanisms. Harvard Univ Press, Cambridge

Taniguchi A, Takeda Y (1988) Feeding rate and behavior of the tintinnid ciliate Favella taraikaensis observed with a high speed VTR system. Mar microb Food Webs 3:21-34

Tollrian R (1993) Neckteeth formation in Daphnia pulex as an example of continuous phenotype plasticity: morphological effects of Chaoborus kairomone concentration and their quantification. J Plankton Res 15:1309-1318

Trager G, Achituv Y, Genin A (1994) Effects of prey escape ability, flow speed, and predator feeding mode on zooplankton capture by barnacles. Mar Biol 120:251-259

Treguer P, Nelson DM, Van Bennekom AJ, DeMaster DJ, Leynaert A, Queguiner B (1995) The silica balance in the world ocean: a reestimate. Science 268:375-379

Turner JT (1991) Zooplankton feeding ecology: do co-occurring copepods compete for the same food? Rev aquat Sci 5:101-195

This article was submitted to the editor
Valiela I (1984) Marine ecological processes. Springer-Verlag, New York

Van Alstyne KL (1986) Effects of phytoplankton taste and smell on feeding behavior of the copepod Centropages hamatus. Mar Ecol Prog Ser 34:187-190

Verity PG (1987) Factors driving changes in the pelagic trophic structure of estuaries, with implications for the Chesapeake Bay. In: Lynch MP, Krome EC (eds) Perspectives on the Chesapeake Bay: recent advances in estuarine sciences. Chesapeake Research Consortium Publ No 127. Gloucester Point, VA, p 35-56

Verity PG (1991) Feeding in planktonic protozoans: evidence for non-random acquisition of prey. J Protozool 38: $69-76$

Verity PG, Stoecker DK (1982) Effects of Olisthodiscus luteus on the growth and abundance of tintinnids. Mar Biol 72: $79-87$

Verity PG, Stoecker DK, Sieracki ME, Nelson JR (1993) Grazing, growth, and mortality of microzooplankton during the 1989 North Atlantic spring bloom at $47^{\circ} \mathrm{N}, 18^{\circ} \mathrm{W}$. Deep Sea Res 40:1793-1814

Verity PG, Villareal TA (1986) The relative food value of diatoms, dinoflagellates, flagellates, and cyanobacteria for tintinnid ciliates. Arch Protistenkd 131:71-84

Verity PG, Villareal TA, Smayda TJ (1988) Ecological investigations of colonial Phaeocystis pouchetii. II. The role of life cycle phenomena in bloom termination. J Plankton Res 10: $749-766$

Vermeij GJ (1994) The evolutionary interaction among species: selection, escalation, and coevolution. A Rev Ecol Syst $25: 219-236$

Vinyard GL (1982) Variable kinematics of Sacramento perch (Archoplites interruptus) capturing evasive and nonevasive prey. Can J Fish Aquat Sci 39:208-211

Walsh JJ (1977) A biological sketchbook for an eastern boundary current. In: Goldberg ED, McCave IN, O'Brien JJ, Steele JH (eds) The sea, Vol 6. John Wiley \& Sons, New York, p 923-968

Wassmann P (1994) Significance of sedimentation for the termination of Phaeocystis blooms. J mar Syst 5:81-100

Werner EE, Hall DJ (1988) Ontogenetic habitat shifts in bluegill: the foraging rate-predation risk tradeoff. Ecology 69:1352-1366

White $\mathrm{HH}$ (1979) Effects of dinoflagellate bioluminescence on the ingestion rates of herbivorous zooplankton. J exp mar Biol Ecol 36:217-224

Yen J, Fields DM (1992) Escape responses of Acartia hudsonica (Copepoda) nauplii from the flow field of Temora longicornis (Copepoda). Arch Hydrobiol Beih 36:123-134

Zaret TM (1980) Predation and freshwater communities. Yale Univ Press, New Haven

Zaret TM, Suffern JS (1976) Vertical migration in zooplankton as a predator avoidance mechanism. Limnol Oceanogr 21. $804-813$

Manuscript first received: March 14, 1995

Revised version accepted: August 23, 1995 